\title{
DOES GENDER MODERATE THE EFFECT OF EARNINGS MANAGEMENT ON FIRM VALUE?
}

\author{
Anjelina \\ Faculty of Economic and Business, University of Airlangga, Indonesia \\ E-mail: anjelina.ina11@gmail.com
}

\begin{abstract}
This study aims to examine the effect of earnings management on firm value with gender as moderating variable (the proportion of female directors). Earnings management is measured by real activities (Roychowdhury, 2006), company value is measured by Tobins'Q and there are growth and size as control variables. This paper uses panel data from 545 firm-years non-financial public company listed on the Indonesia Stock Exchange in the period 20112015. Data analysis method uses panel data regression analysis with the selection of Random Effect models through STATA software. The results of this analysis reveal, first earnings management has a negative effect on firm value, while the control variables used do not affect the firm value. Second, the proportion of female directors (gender) does not moderate the relationship between earnings management and firm value. This paper provides empirical evidence for management related to investors' response to real earnings management activities and provide an overview to the government, especially tax policy makers in order to anticipate earnings management behavior that has a negative impact on state revenues.
\end{abstract}

\section{KEY WORDS}

Earnings, management, firm value, gender.

Profit can provide a positive signal about the company's prospects in the future because profit growth that continues to increase from year to year will increase the value of the company reflected in the company's shares. According to Fuad et al. (2006) an indicator of firm value is the stock price traded on the stock exchange for a company that sells its shares to the public. The presence of firm value indicators reflected in stock prices encourages companies to report earnings so that investors respond well to the value of the company. Profit becomes one of the important components which is the main consideration in making decisions and the center of attention for decision makers or users of financial statements.

Management will report profits in accordance with the desired goals through earnings management. Earnings management is a managerial action that is reflected in financial statements to give a smooth earning impression periodically or annually (Gill et al, 2013). Generally, management uses various accounting methods to convey private information to readers. Earnings management activities can be done in two ways, through accrual deskretionary and real activity. Real earnings management can be done through actual transactions that affect cash flows directly (Huang et al., 2009). Accrual management refers to the opportunistic behavior of companies to achieve income targets through accruals, changes in accrual management through accounting books do not change the company's cash flow ( $\mathrm{Na}$ and Hong, 2017). Earnings management can be regarded as one of the effects of agency conflict, this occurs when the principal cannot fully or completely monitoring all the activities carried out by the agent whether the activity is in accordance with the principal's objectives (Imhoff, 1978). Too much earnings management will reduce the ability of investors to interpret current income, especially if earnings management is hidden behind the principal opinion and not fully disclosed. Excessive earnings management can reduce benefits (Soetedjo, 2009).

Based on the prospect theory that investors like a certain profit pattern, which is a form of the function of the prospect theory that causes management to make a creation of reported earnings (Suartana, 2010). Prospect theory can explain motivation for managers to 
meet income thresholds (Kahneman \& Tversky, 1979). Motivation for companies to practice earnings management is found to be different depending on the type of industry being considered, with motivation to manage income and avoid decreasing income reporting (reporting decreases) becoming more common than motivation to avoid reporting losses (Niloufar \& Nejad, 2015 )

Previous research related to the effect of earnings management on firm value showed varied results. Earnings management has a positive effect on firm value (Challen and Siregar, 2011, Huang et al., 2009 and Oktavia, 2011). Earnings management has a negative effect on firm value (Zhang et al., 2006). There is no influence of earnings management on firm value (Ujiyanto, 2007, and Yip and Nguyen, 2011).

Gender perspectives can increase understanding of the extent of involvement in accounting manipulation. Gender has implications for engaging in certain behaviors, genderbased explanations will clarify socio-cultural decisions. There is a negative relationship between the proportion of female directors and earnings management. Female directors increase board oversight because they limit earnings management more than men. A group that has greater diversity has better performance than a homogeneous group, even though there are competent people in that group (Ernest and Young, 2009). When a CEO or CFO is a woman earnings management is significantly lower, thus the presence of women serves as internal monitoring (Gavious et al., 2012).

According to Morisson et al. (2004) women complement men in management and will bring a healthy balance to business. CPAs that work in organizations with high ethical standards consider the activities of earnings management unethical (Elias, 2004). Some studies also show that women tend to take less risk or risk averse than men (Barber and Odean, 2001, Niessen and Ruenzi, 2006 and Wei and Xie, 2010), women perform tasks by judging morally (Eccles, 1994), and the presence of women increases the function and efficiency of BOD and firm value (Huse and Solberg, 2006), and Liu et al. (2014) also stated that having female members in audit committees tended to improve the performance of companies and they tended to take less risk. According to $\mathrm{Na}$ et al. (2017) CEOs and CFOs have different roles in managerial decisions, CEOs have strength in corporate decision making while CFOs are responsible for corporate financial reporting, therefore gender CEOs can influence company earnings management, in contrast to CFOs. The results of this study indicate that male CEOs use discretionary accruals aggressively while earnings management practices do not occur in the female CEO group.

\section{LITERATURE REVIEW}

Earnings Management, Gender and Firm Value. Earnings management is a management action to choose an accounting policy from a certain standard in order to achieve a certain profit target, with the aim of maximizing the welfare of the management or firm value (Scott, 2009). The alternative to choosing this accounting policy gives management discretionary authority to make choices between available alternative practices and that leads to financial facts that will be manipulated (Kumari et al., 2015). Each type of financial reporting manipulation action will create a shadow view of actual facts and encourage earnings management practices in the business (Beatty et al., 2002). One example of earnings management actions that managers can take is to overestimate the ending inventory to manipulate cost of goods sold. Earnings management can also be interpreted as a change in the company's economy which is reported by insiders to mislead several stakeholders or to influence the outcome of the contract (Healey and Wahlen, 1999). Whereas Schiper et al., 1999 defines earnings management as a deliberate intervention in the external financial reporting process with the aim of obtaining some personal benefits by the manager. Earnings management affects the value of the company. The results of Gill et al. (2013) showed that the higher the practice of earnings management, the greater the adverse effect on the level of ROA in the following year.

Gender diversity can improve a company's financial performance with weak governance (Adam and Ferreira, 2009). The quality of financial reporting depends on 
managerial motives, intensive and opportunism of corporate executives that influence earnings management. Gender executives and company directors influence company performance, thus it can be said that the executive gender influences managerial behavior (Peni and Vahamaa, 2010). Kyaw et al. (2015) found that female directors reduce earnings management, with conditions when gender equality is high. This research highlights the importance of empowering women in the workplace by benefiting from this gender diversity. Companies with female CEOs have less management than male CEOs and there is a negative relationship between female executives and earnings management (Thiruvadi, 2011):

$\mathrm{H} 1$ : Earnings management affects the firm value;

$\mathrm{H} 2$ : the proportion of female directors (gender) moderates the effects of earnings management on firm value.

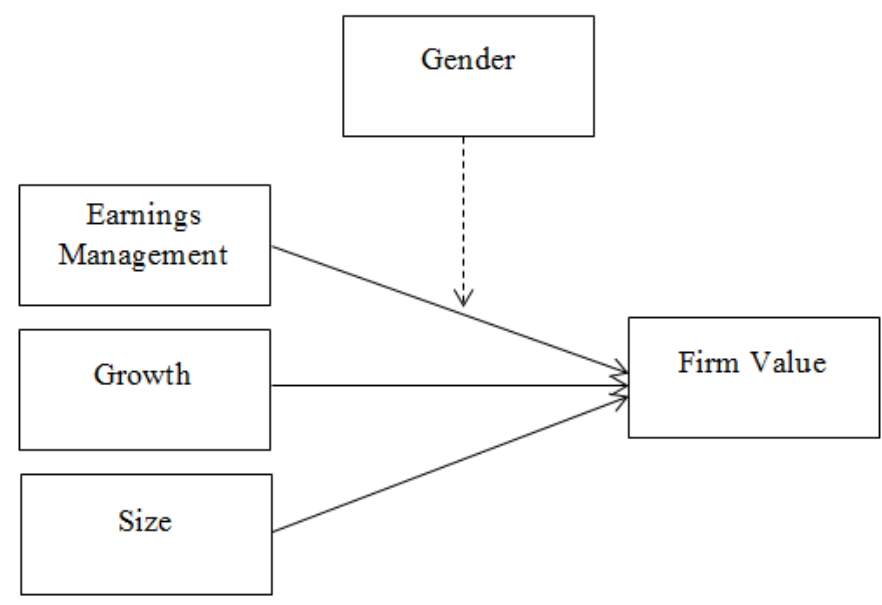

Figure 1 - Conceptual Framework

\section{METHODS OF RESEARCH}

The population in this study were public companies listed on the Indonesia Stock Exchange (IDX) for the period 2011 to 2015. The method of sampling in this study was conducted by purposive sampling with the criteria of (1) non-financial public companies listed on the IDX in the period 2011 - 2015 and (2) the availability of complete data to be used in this study.

The mathematical model used to test the hypotheses developed in this study follows Huang et al. (2009), Siregar and Utama (2008):

$$
\text { TOBIN'SQ } Q_{i t}=\beta_{0}+\beta_{1} R E A L_{i t}+\beta_{2} G_{E N D E R_{i t}} \times R E A L_{i t}+\beta_{3} \text { GROWTH }_{i t}+\beta_{4} \text { Size }+\varepsilon_{i t}
$$

The dependent variable of this study is the firm value that is proxied by Tobin's Q (Huang, et al., 2009 and Ammann, et al., 2011) with the following formula:

$$
\text { Tobin's } Q_{i t}=\frac{M V E_{i t}+B V A_{i t}-B V E_{i t}}{T A_{i t}}
$$

Where: MVE - Equity market value or market capitalization, calculated from the closing stock price multiplied by the number of outstanding shares; BVA - Book value of assets, measured by Total Assets; BE - book value of equity, measured by Total Equity; TA - Total Assets; it for each company i year $t$.

Independent variables consist of earnings management through real activities. Earnings management through real activity is measured by the estimated value of manipulated sales. Measurement of earnings management adopts the method used by Roychowdhury (2006). The models tested in this study are: 


$$
\text { CFO }_{i t} / A_{i t-1}=\beta_{0}+\beta_{1} 1 / A_{i t-1}+\beta_{2} \text { Sales }_{i t} / A_{i t-1}+\beta_{3} \Delta \text { Sales }_{i t} / A_{i t-1}+e_{i t}
$$

Where: CFO - cash flow from operation; $A_{i t-1:}$ total assets from year $t-1$ to year $t$; Sales: sales from company to year $\mathrm{t}$; $\Delta$ Sales: sales changes from year $\mathrm{t}-1$ to year $\mathrm{t}$.

The moderating variable of this study is gender, which is measured by the proportion of the structure / composition of female board members.

The control variables in this study are:

- Growth. Sustainable growth can be a positive signal to investors. Developing companies will also be valued by investors better (Allayannis et al., 2012). Following the study of Oktavia (2011), the growth rate is proxied by using changes in sales. GROWTH $=\left(\mathrm{SALE}_{\mathrm{it}} \mathrm{SALE}_{\mathrm{it}-1}\right) / \mathrm{SALE}_{\mathrm{it}-1}$

- Size. Size is measured by total assets. Companies that have large total assets show that the company is relatively more stable and able to generate greater profits than companies that have little or low total assets.

\section{RESULTS OF STUDY}

Based on data from the Indonesia Stock Exchange, a total of 109 companies were obtained per year that had complete data from 2011 to 2015 or 545 observations (firm-year).

Table 1 - Descriptive Statistics

\begin{tabular}{ccccc}
\hline Variable & Mean & Maximum & Minimum & Std Dev \\
\hline TobinsQ1 & .2193107 & 5.818928 & -3.182037 & .7653035 \\
RealEM & .2420499 & 4.229934 & -.0248292 & .4443329 \\
Growth & .237532 & 4.229934 & -.9988356 & 1.089752 \\
Size & 28.67637 & 36.24761 & 23.54591 & 1.880578 \\
pdw & .1176074 & 1 & 0 & .2024677 \\
\hline
\end{tabular}

Source: Data processed, 2018.

This study uses panel data. Panel data is an observation set consisting of several individuals in a given period. In panel data testing does not require an autocorrelation-free and normality equation Nachrowi and Usman (2006). For panel data regression estimation methods can be through three approaches, namely Pooled Least Square Model, Fixed Effect Model and Random Effect Model. To choose which model is most suitable for processing panel data, there are several tests that can be done. This research regression model has fulfilled the assumption of multicollinearity. Statistical output from the regression model for multicollinearity test based on Tolerance and VIF values can be concluded that there is no multicollinearity in the regression model because all VIF values are below 10 . Testing of this hypothesis is done through the STATA 13 program by selecting the Random Effect Model.

Table 1 shows the descriptive statistics of the variables contained in model 1 which examine the effect of real earnings management on firm value by moderating the proportion of female directors. Based on Table 1, the average company that becomes the sample has a value of tobins $Q$ (dependent variable) of 0.2193107 . While the maximum tobins $q$ value is 5.818928 and the minimum value is -3.182037 .

Tabel 2 - The test results for the assumption of multicollinearity

\begin{tabular}{ccc}
\hline Variable & VIF & $1 /$ VIF \\
\hline Size & 1,37 & 0,728792 \\
Real EM & 1,31 & 0,764605 \\
Growth & 1,07 & 0,938369 \\
Mean VIF & 1,25 & \\
\hline
\end{tabular}

Source: Data processed, 2018.

For the independent variable, Real Earnings Management (RealEM), the average REAL sample of the company is .2420499, while the maximum value is 4.229934 and the 
minimum value is -.0248292 . The moderating variable is in the form of female directors (gender) in the structure of the board of directors, on average the sample companies are led by female directors as much as $28.67 \%$, and the maximum is led by $100 \%$ of the minimum amount of 0 .

Table 3 - Hypothesis Test Results Effect of Earnings Management on Firm Value

\begin{tabular}{cccc}
\hline Variable & Coefficient & $\mathrm{z}$ & $\mathrm{P}>|\mathrm{z}|$ \\
\hline RealEM & -.1188016 & -2.12 & 0.034 \\
Growth & -.0124655 & -0.52 & 0.600 \\
Size & .0361689 & 1.54 & 0.123 \\
Constanta & -.7861644 & -1.17 & 0.244 \\
R-sq & & & 0.0184 \\
Prob $>$ chi2 & & & 0.0697 \\
\hline
\end{tabular}

Source: Data processed, 2018.

Table 4 - Hypothesis Test Results Effect of Real Earning Management on Company Values with the proportion of Female Directors (Gender) as Moderation

\begin{tabular}{cccc}
\hline Variable & Coefficient & $\mathrm{Z}$ & $\mathrm{P}>|\mathrm{z}|$ \\
\hline RealEM & -.1417162 & -2.27 & 0.023 \\
Growth & -.0132889 & -0.56 & 0.576 \\
Size & .0361291 & 1.54 & 0.124 \\
RealEMxPFD & .2934335 & 0.82 & 0.410 \\
Constanta & -.7861603 & -1.16 & 0.245 \\
R-sq & & & 0.0188 \\
Prob $>$ chi2 & & 0.1018 \\
\hline
\end{tabular}

Source: Data processed, 2018.

Testing the hypothesis 1 states that real earnings management has an effect on the firm value can be accepted at a significance level of $5 \%$. Based on the regression results, Table 3 in general model 1 is significant $(p<0.05)$ and R-squared is $1.84 \%$. With these results that together the variation of the independent variables used in this research model is able to explain the variation of the dependent variable by $1.84 \%$. while the rest is explained by other variables outside of this model. The negative coefficient sign on real earnings management shows that the low real earnings management activity in order to improve company performance. The discovery of the negative effect of real earnings management on company performance, illustrates that the higher real earnings management activities carried out by management will further decrease the firm value and vice versa. This is in line with the results of research such as Zhang et al (2006). The control variable in this study is growth and size does not affect the company's performance.

Table 4 shows the hypothesis test of the effect of real earning management on firm performance with the proportion of female directors as moderation. The main independent variable used to test this model is real earnings management, while the moderating variable is the proportion of female directors. Testing of hypothesis 2 which states that real earnings management has an effect on company performance by moderating the proportion of female directors is rejected. This shows that the number of women in the board of directors does not weaken or strengthen the relationship of earnings management to firm value.

\section{CONCLUSION}

The main theories used in this study are prospect theory, agency theory, and signal theory. Some conclusions that can be taken from the results of testing in this study are as follows: first, the effect of earnings management on firm value. In general, the study found the effect of earnings management activities on firm value. With the better the company in conducting earnings management activities will further reduce the firm value. Second, that gender or the proportion of female directors do not moderate the relationship of earnings management to company performance. 
The limitations of this study are not included in the same test as the measurement of the earnings management model that is different from the Roychowdhury (2006) model for comparison. The suggestions for further research, the measurement of company value can also be proxied by stock returns and abnormal returns or cumulative abnormal returns. The results of this study are also expected to provide an overview of real earnings management in Indonesia, so that the government can anticipate real earnings management behavior which will negatively affect company performance, one of which is to reduce state cash receipts through taxes.

\section{REFERENCES}

1. Adams, R.B. and Ferreira, D. (2009), "Women in the boardroom and their impact on governance and performance", Journal of Financial Economics, Vol. 94, pp. 291-309.

2. Ammann, M., Oesch, D., dan Schmid, M. M. (2011). Corporate governance and firm value: International evidence. Journal of Empirical Finance, 18, 36-55.

3. Barber, Brad M dan Odean, Terrance. (2001). Boys Will Be Boys: Gender, Overconfidence And Common Stock Investment. The Quarterl Journal Of Economics.

4. Beatty, A.L., Bin Ke, and Petroni K.R. (2002). Earnings management to avoid earnings declines across publicly and privately held banks. The Accounting Review, 7.

5. Challen, A. E. and Siregar, S. V. (2011). The Effect of Audit Quality on Earnings Management and Firm Value, Working paper. Presented at The 12th Asian Academic Accounting Association, Bali, Indonesia.

6. Eccles, J.S. (1994), “Understanding women's educational and occupational choices: applying the Eccles et al. model of achievement-related choices", Psychology of Women Quarterly.

7. Elias, R. Z., 2004. "The Impact of Corporate Ethical Values on Perceptions of Earnings Management". Managerial Auditing Journal 19 (1).

8. Fuad, M., H, C., Nurlela, Sugiarto, \& Y.E.F, P. 2006. Pengantar Bisnis. Jakarta: Gramedia Pustaka Utama.

9. Gill, Amarjit., Biger, Nahun., Maud, Harvinder, S., dan Mathur, Neil. (2013). Earnings management, Firm Performance, and the Value of Indian Manufacturing Firms. International Research Journal of Finance and Economics.

10. Gavious, Ilanit., Segev, Einav., dan Yosev, Rami. (2012). Female Directors and Earnings Mannagement in High-Technology Firms. Pacificc Acounting Review, 24.

11. Healy, Paul M. (1985). The Effect of Bonus Schemes On Accounting Decisions. Journal of Accounting and Economics, 7, 85-107.

12. Healy, P. and J.M. Wahlen, 1999. "A review of the earnings management literature and its implications for standard setting," Accounting Horizons.

13. Huang, P., Zhang, Y., Deis, Donald R., dan Moffitt, J. S. (2009). Do artificial income smoothing and real income smoothing contribute to firm value equivalenty? Journal of Banking \& Finance, 33, 224-233.

14. Huse, M. and Solberg, A. (2006), "Gender-related boardroom dynamics: how Scandinavian women make and can make contributions on corporate boards", Women in Management Review, Vol. 21, pp. 113-30.

15. Imhoff, E. A, 1978. "The Representativeness of Management Earnings Forecast". The Accounting Review, 53

16. Kahneman, Daniel dan Tversky, Amos. (1979). Prospect Theory: an Analysis of Decision Under Risk. Econometrica,Vol. 47.

17. Kumari, Prity dan Pattanayak, J,K. (2015). Earning Management and Firm Performance: an Insight into Indian Commercial Banks. Journal of Scientific Research and Development.

18. Kyaw, Khine., Olugbode, Mojisola., dan Petracci, Barbara. (2015). Does gender diverse board mean less earnings management. Finance Research Letters xxx.

19. Liu, Y., Wei, Z., \& Xie, F. (2014). Do women directors improve firm performance in China? Journal of Corporate Finance, Vol. 28. 
20. Morrison, A.M., Randall, P.W., Van Valsor, E. and The Center for Creative Leadership (2004), Breaking the Glass Ceiling, Addison-Wesley, Boston, MA.

21. Na, Kyunga dan Hong, Jooyeon. (2017). CEO Gender and Earnings Management. The Journal of Applied Business Research, Vol. 33.

22. Nachrowi, Nachrowi D. dan Usman, H. (2006). Pendekatan Populer dan Praktis Ekonometrika Untuk Analisis Ekonomi dan Keuangan. Jakarta: Lembaga Penerbit Fakultas Ekonomi Unversitas Indonesia.

23. Niloufar, S.W dan Nejad, R. (2015). Prospect theory, industry characteristics and earnings management: a study of Malaysian industries. Review of Accounting and Finance, Vol. 14.

24. Niessen, A., \& Ruenzi, S. (2006). Sex matters: Gender and mutual funds. manuscript, University of Cologne.

25. Oktavia. (2011). "Motivasi Penggunaan Derivatif Pada Perusahaan Publik di Indonesia". Tesis Program Pascasarjana IImu Akuntansi. Universitas Indonesia.

26. Peni, Emilia dan Vahamaa, Sama. (2010). Female executives and earnings management. Managerial Finance, Vol. 36.

27. Roychowdury, Sugata. (2006). Earnings management through real activities manipulation. Journal of Accounting and Economics, 42, 335-370.

28. Schipper, K (1989), Commentary on earnings management. Accounting Horizons, 3.

29. Scott, William R. (2009). Financial Accounting Theory. $5^{\text {th }}$ edition. Prentice Hall.

30. Siregar, S. V. dan Utama, S. (2008). Type of earnings management and the effect of ownership structure, firm size, and corporate-governance practice: Evidence from Indonesia. The International Journal of Accounting, 43, 1-27.

31. Suartana, I.W. (2010). Akuntansi Keperilakuan Teori dan Implementasi. Yogyakarta: Penerbit ANDI

32. Thiruvadi, S dan Huang, Hua-Wei. (2011). Audit committee gender differences and earnings management. Gender in Management: An International Journal, 26(7).

33. Ujiyanto, M.A dan Pramuka, B.A. (2007). Mekanisme Corporate Governance, Manajemen Laba dan Kinerja Keuangan. Simposium Nasional Akuntansi X.

34. Wei, Zuobao dan Xie, Feixue. (2010). CFO Gender and Earnings Management: Evidence from China. Review of Quantitative Finance and Accounting.

35. Yip, W. H., dan Nguyen, H. (2012). Exchange rate exposure and the use of foreign currency derivatives in the Australian resources sector. Journal of Multinational Financial Management, 22, 151-167.

36. Zhang, Yan, Zhou, J., dan Zhou, N. (2007). Audit committee quality, auditor independence, and internal control weaknesses. Journal of Accounting and Public Policy, $26,300-327$. 